\title{
PENGEMBANGAN PERANGKAT PEMBELAJARAN DENGAN MODEL GENIUS LEARNING STRATEGY PADA MATERI BARISAN DAN DERET SMP NEGERI 4 GOLEWA
}

\author{
Maria Editha Bela \\ Pendidikan Matematika, STKIP Citra Bakti Ngada \\ itabella09@gmail.com
}

\begin{abstract}
Abstrak
Penelitian ini bertujuan untuk mengembangkan perangkat pembelajaran matematika yang valid, praktis dan efektif dengan model Genius Laerning Strategi (GLS) pada materi barisan dan deret untuk siswa kelas IX SMP Negeri 4 Golewa. Rancangan penelitian yang diqunakan adalah rancangan model pengembangan Plomp yang terdiri atas 3 fase yaitu: (a) Penelitian Awal (Preliminary Research), (b) Fase pengembangan (Prototyping Phase) (c) Fase Penilaian (Assessment Phase). Perangkat yang dikembangkan pada penelitian ini berupa Lembar Keria Siswa (LKS). Hasil penelitian menunjukkan bahwa perangkat pembalajaran tersebut Valid. Hal ini dituniukkan oleh hasil validasi yang dilakukan oleh dua validator yang berbeda. Kepraktisan didapat dari hasil observasi keterlaksanaan aktivitas guru dan menunjukkan kriteria baik. Sedangkan keefektifan dinilai dari tiga hal, yaitu observasi aktivitas siswa dan hasil respon siswa dengan kategori baik dan positif.
\end{abstract}

Kata Kunci: Perangkat Pembelajaran, Genius Learning Strategy, Barisan Dan Deret

\section{Abstract}

This research aimed at developing Mathematics learning devices which valid, practical, and effective with Genius Laerning Strategi (GLS)model in line and series materials of class IX SMP Negeri 4 Golewa. The research design used was Plomp development model design consisted of three phases, which were: Preliminary Research, Prototyping Phase, and Assessment Phase. The devices developed in this research were Students Worksheet. The result of research showed that the learning devices were valid. This indicated by the result of validation which done by two different valuators. The practicality was obtaining from the result of observing the implementation of the teacher activities and showed good criteria. Whereas the effectiveness was judged by three things namely the observation of students activity and the result of students responds in good and positive category.

Keywords: learning devices, genius learning strategy, line and series materials

\section{PENDAHULUAN}

Perangkat pembelajaran merupakan suatu hal yang sangat penting dalam melaksanakan proses pembelajaran. Perangkat pembelajaran tersebut terdiri dari sejumlah bahan, alat, media, petunjuk dan pedoman yang akan digunakan dalam proses pembelajaran (Azhar, 2011). 
Selanjutnya metode dan perangkat pembelajaran tersebut haruslah mendukung ketercapaian tujuan pembelajaran, dalam hal ini pembelajaran matematika.

Tujuan pembelajaran matematika di setiap jenjang pada sadarnya mengacu pada dua tujuan pokok yaitu tujuan yang bersifat formal dan material (Soedjadi, 2000). Tujuan yang bersifat formal menekankan pada penataan nalar serta pembentukan pribadi siswa. Sedangkan tujuan yang bersifat material menekankan pada kemampuan pemecahan masalah dan penerapan matematika baik dalam bidang matematika maupun bidang ilmu lainnya. Matematika adalah mata pelajaran yang sangat penting bagi peserta didik. Tujuan diberikannya pembelajaran matematika di sekolah adalah untuk mempersiapkan peserta didik agar bisa menghadapi perubahan kehidupan dan dunia yang selalu berkembang melalui latihan bertindak atas dasar pemikiran logis, rasional dan kritis (Bela, 2018). Namun banyak kesulitan yang ada dan merambahhampir ke suluruh komponen pembelajaran matematika, mulai dari faktor interen misalnya siswa, guru, kurikulum sarana dan prasarana yang belum memadai sampai pada faktor eksternal yaitu pentingnya peran orang tua dan lingkungan masyarakat.

Berbagai inovasi pembelajaran matematika telah banyak dilakukan untuk mengatasi problematika pembelajaran matematika di sekolah saat ini Untuk melaksanakan pembelajaran matematika yang menekankan situasi peserta didik belajar diperlukan suatu strategi, metode, pendekatan dan teknik yang membuat peserta didik aktif dalam pembelajaran. Semua orang yakin bahwa guru memiliki andil yang sangat besar terhadap keberhasilan pembelajaran di sekolah. Guna mewujudkannya, guru merancang Perangkat Pembelajaran. Perangkat Pembelajaran efektif ketika tujuan pembelajaran dapat dicapai oleh siswa, sehingga hasil belajar siswa pun baik. Salah satu model pembelajaran yang dapat mewujudkan hal itu adalah Genius Learning Srategy (GLS).

Genius Learning Strategy (GLS) adalah sebuah model pembelajaran yang berangkat 
dengan satu keyakinan dan pengharapan bahwa apabila setiap siswa dapat dimotivasi dengan tepat dan dididik dengan cara yang benar, cara yang menghargai keunikan mereka, sehingga mereka dapat mencapai suatu hasil pembelajaran matematika yang maksimal. Dalam Genius Learning Strategy (GLS), guru menempatkan anak sebagai pusat dari proses pembelajaran matematika, yaitu sebagai subyek pendidikan. Terdapat 8 fase yang diberi nama Lingkaran Sukses Genius Learning Strategy (GLS), meliputi (1) Suasana Kondusif, (2) Hubungkan, (3) Gambaran Besar,

(4) Tetapkan Tujuan, Pemasukan Informasi, (6) Aktivasi, (7) Demonstrasi, dan (8) Ulangi dan Jangkarkan. Materi yang dipilih dalam penelitian ini adalah Barisan dan Beret di kelas 9, karena materi ini merupakan awal dari siswa mempelajari tentang barisan dan deret aritmatika/geometri. Sehingga diharapkan siswa mampu menguasai yang selanjutnya lebih dalam saat duduk di bangku SMA/SMK.

Untuk memiliki kualifikasi akademik dan kompetensi serta meningkatkan kemampuan matematika peserta didik maka guru mata pelajaran matematika sebagai fasilitator perlu menciptakan proses pembelajaran yang menarik. Menurut Peraturan Pemerintah Nomor 32 tahun 2013 tentang Standar Nasional Pendidikan menyatakan bahwa pendidik harus memiliki kualifikasi akademik dan kompetensi sebagai agen pembelajaran, sehat jasmani dan rohani, serta memiliki kemampuan untuk mewujudkan tujuan pendidikan nasional. Yang dimaksud pendidik sebagai agen pembelajaran (learning agent) adalah peran pendidik antara lain sebagai fasilitator, motivator, pemacu, dan pemberi inspirasi belajar bagi peserta didik. Menurut Peraturan Menteri Tahun 2013 tentang standar nasional pendidikan tinggi menyatakan bahwa proses pembelajaran harus dilaksanakan secara interaktif, menyenangkan, menantang dan memotivasi mahasiswa untuk berpartisipasi aktif, serta memberikan kesempatan untuk berkreativitas dan mandiri. Oleh karena iti, sangatlah penting untuk mengembangkan suatu perangkat pembalajaran yang mengaplikasikan suatu model 
pembelajaran yang berpusat pada siswa dan mampu mengembangkan daya nalar yang dimiliki oleh siswa.

\section{Genius Learning Strategy}

(GLS) adalah istilah yang digunakan untuk menjelaskan suatu rangkaian pendekatan praktis dalam upaya meningkatkan hasil proses pembelajaran. Dasar dari Genius Learning Strategy (GLS) ini adalah metode Accelerated Learning yang kali pertama dikembangkan oleh Dr.Goergi Lozanov, seorang psikiater Bulgaria. Diluar negeri metode accelerated learning dikenal dengan berbagai nama, seperti Quantum Teaching, Quantum Learning, Super Learning, Efficient and Effective Learning. Pada intinya tujuan dari berbagai metode ini sama yaitu bagaimana membuat proses pembelajaran menjadi efesien, efektif, dan menyenangkan. Nama Genius Learning diberikan oleh Adi W. Gunawan untuk membedakan model accelerated learning yang dikembangkan dengan model sejenis yang ada di masyarakat. Yaitu menyiapkan anak-anak kita untuk bisa menjalani hidupnya dengan berhasil.
Untuk

menciptakan lingkungan belajar GLS, baik guru maupun siswa harus bisa merasakan (1) perasaan diterima dan menjadi bagian dari kelas/sekolah, (2) perasaan dapat dan mampu melakukan suatu kontribusi yang positif dan dapat berhasil di dalam kelas/sekolah, dan (3) perasaan aman secara fisik dan psikis di dalam kelas/sekolah.Genius Learning Strategy (GLS) adalah cara belajar yang memiliki 8 fase, yaitu (1) Suasana Kondusif artinya guru bertanggungjawab untuk menciptakan iklim belajar yang membebaskan siswa dari rasa takut dan tekanan psikologis untuk belajar, (2) Hubungkan artinya menghubungkan antara materi yang akan dipelajari dengan pengetahuan yang telah diketahui oleh siswa dari proses pembelajaran sebelumnya atau dari pengalaman siswa itu sendiri, (3) Gambaran Besar artinya memberikan perintah kepada pikiran siswa untuk menciptakan folder yang nantinya akan diisi dengan informasi, (4) Tetapkan Tujuan artinya penyamapaian hasil yang akan dicapai pada akhir pembelajaran, (5) Pemasukan 
Informasi artinya penyampaian pembelajaran yang melibatkan berbagai gaya belajar siswa, (6) Aktivasi artinya proses yang membawa siswa kepada satu tingkat pemahaman yang lebih dalam terhadap materi yang diajarkan, (7) Demonstrasi artinya guru memberikan ujian yang digunakan untuk mengetahui sampai di mana pemahaman siswa dan sekaligus memberikan umpan balik kepada siswa, dan (8) Ulangi dan Jangkarkan artinya guru membimbing siswa untuk membuat kesimpulan dari apa yang telah mereka pelajari hari ini.

Tujuan dari penelitian ini adalah untuk mengembangkan perangkat pembelajaran matematika dengan menggunakan model Genius Learning Strategy (GLS) pada materi Barisan dan Deret untuk siswa Kelas IX SMP yang valid, praktis dan efektif. Dalam penelitian ini, peneliti mengembangkan perangkat pembelajaran yang meliputi Lembar Kerja Siswa (LKS) dengan model Genius Learning Strategy(GLS) pada materi Barisan dan Deret di Kelas IX siswa SMP. Perangkat yang dikembangkan pada penelitian ini adalah Lembar
Kerja Siswa (LKS). Penyusunan Lembar Kerja Siswa (LKS) yang tepat sangatlah diperlukan agar guru dapat melaksanakan proses Genius Learning Strategy dengan benar sehingga mampu merangsang siswa untuk menjadi tertarik dengan pembelajaran yang diterapkan.

\section{METODE PENELITIAN}

Penelitian ini menggunakan rancangan penelitian model pengembangan Plomp yang terdiri dari 3 fase yaitu: (a) Penelitian Awal (Preliminary Research), (b) Fase Pengembangan (Prototyping Phase) dan (c) Fase Penilaian (Assessment Phase). Pada penelitian awal (Preliminary Research) dilakukan pengamatan dan analisis perilaku siswa dalam kegiatan pembelajaran di kelas IX SMP Negeri 4 Golewa selama delapan jam pelajaran, pengkajian kurikulum tahun 2013 dan silabus tentang materi barisan dan deret, serta investasi sumber-sumber pendukung yang digunakan oleh guru dalam pembelajaran. Hal ini dibutuhkan untuk selanjutnya dijadikan acuan dalam penyusunan perangkat pembelajaran model 
Genius Learning Strategy (GLS) yang akan dikembangkan.

Selanjutnya, pada fase pengembangan

(Prototyping

Phase), dilaksanakan pengembangan produk yang mendukung pembelajaran matematika model Genius Learning Strategy (GLS). Pada tahap ini, tidak hanya produk penelitian yang telah dikembangkan tetapi juga instrumen penilaian yang digunakan untuk mengukur kevalidan, kepraktisan dan keefektifan produk hasil penelitian. Produk yang dikemabngkan adalah Lemabar Kerja Siswa (LKS) yang disusun berdasarkan prosedur model Genius Learning Strategy. Lembar Kerja Siswa ini berfungsi sebagai pedoman bagi siswa untuk dapat mengikuti alur model Genius Learning Strategy yang dilaksanakan oleh guru. Sedangkan instrument penilaian yang dikembangkan pada fase ini berupa (a) lembar validasi perangkat pembelajaran dan istrumen penilaian, (b) lembar observasi aktivitas guru, (c) lembar observasi aktivitas siswa, dan (d) angket respon siswa.
Tahap terakhir yang dilakukan adalah fase penilaian (Assessment Phase). Untuk memenuhi syarat valid, praktis dan efektif, produk yang telah dikembangkan pada fase sebelumnya yaitu Lembar Kerja Siswa dilaksanakan dua tahap penilaian. Tahap pertama adalah uji validasi untuk mengukur kevalidan produk dan instrumen penilaian yang selanjutnya juga akan digunakan untuk mengukur kepraktisan dan keefektifan produk. Uji validasi ini dilakukan oleh dua validator. Instrument yang digunakan adalah lembar validasi perangkat pembelajaran dan instrument penilaian. Dua validator tersebut adalah para ahli dan praktisi di bidang pembelajaran matematika. Selanjutnya, setelah revisi uji validasi telah dirampung dilaksanakan, produk penelitian ini diujicobakan pada sebuah kelompok kecil sebelum akhirnya diujikan pada kelompok yang lebih besar untuk mengukur kepraktisan dan keefektifan produk.

Pelaksanaaan kelompok
kecil dilaksanakan kepada 10
siswa kelas IX SMP Negeri 4
Golewa. Hasil analisis uji coba
tersebut digunakan untuk merevisi


produk hingga produk tersebut siap untuk diujicobakan kembali pada kelompok yang lebih besar. Uji coba kelompok besar dilaksanakan dengan menyertakan dua orang observer yang bertugas untuk menilai keterlaksanaan uji coba tersebut, satu observer mengamati aktivitas guru dengan menggunakan lembar aktivitas guru dan satu observer mengamati aktivitas siswa dengan menggunakan lembar aktivitas siswa. Hasil analisis lembar aktivitas guru digunakan untuk memperoleh hasil kepraktisan produk, sedangkan keefektifan produk diperoleh dari hasil analisis lembar aktivitas siswa dan angket respon siswa.

\section{HASIL DAN PEMBAHASAN}

Hasil pengembangan ini membahas tentang penyajian data dan analisisnya untuk mengukur kevalidan, kepraktisan dan keefektifan perangkat pembelajaran. Pengembangan perangkat pembelajaran adalah Lembar Kerja Siswa yang dikembangkan dengan menggunakan langkah-langkah pengembangan Plomp (2010) yaitu (a) penelitian awal (preliminary research), (b) fase pengembangan (prototyping phase) dan (c) fase penilaian (assessment phase).

\section{Hasil Penelitian Awal (Preliminary Research)}

Penelitian awal dalam pengembangan perangkat pembelajaran ini mencakup tiga hal yaitu investigasi pengetahuan prasyarat, mengamati aktivitas siswa dalam pembelajaran. Hasil pengamatan pengetahuan prasyarat menunjukkan bahwa untuk mengajarkan materi Barisan dan Deret, pengetahuan tentang fungsi, operasi penjumlahan, perkalian dan perpangkatandiperlukan oleh siswa. Hasil pengamatan terhadap pembelajaran di SMP Negeri 4 Golewa menunjukkan hasil yang cukup baik. Guru telah menggunakan beberapa strategi dalam kegiatan pembelajaran di kelas walau terkadang lebih sering hanya memberi materi ceramah dan latihan soal.

\section{Hasil Fase Pengembangan (Prototyping Phase) \\ Pada fase pengembangan ini, penulis mengembangkan perangkat pembelajaran berupa Lembar Kerja Siswa (LKS). Peneliti juga menetapkan acuan materi}


barisan dan deret dari berbagai sumber yang sudah disesuaikan dengan silabus pada SMP.

\section{Hasil Fase Penilaian (Assessment Phase)}

Hasil fase ini dibagi menjadi dua, yaitu hasil validasi dan hasil uji coba lapangan. Hasil validasi digunakan untuk menganalisa kevalidan perangkat yang dikembangkan, sedangkan hasil ujicoba digunakan untuk mengukur kepraktisan dan keefektifan produk.

\section{Hasil Validasi}

Hasil validasi dibagi menjadi dua yaitu hasil validasi perangkat pembelajaran dan hasil validasi instrumen penilaian. Proses validasi dilakukan dengan menyerahkan perangkat, instrumen penilaian dan lembar validasi kepada validator.

Hasil validasi terhadap Lembar Kerja Siswa (LKS) yang dilakukan oleh dua validator menunjukkan rata-rata keseluruhan skor validasi Lembar Kerja Siswa (LKS) 3,25 dan persentase ratarata keseluruhan validasi LKS adalah $81,56 \%$. Maka berdasarkan kriteria kevalidan, prototipe LKS memenuhi kriteria valid. Selain mengisi lembar penilaian validasi, para validator juga memberi beberapa catatan, saran dan komentar kepada peneliti untuk memperbaiki beberapa isi dari Lembar Kerja Siswa. Sedangkan hasil validasi terhadap instrumen penilaian dibagi menjadi 4 yaitu hasil validasi lembar observasi aktivitas siswa, hasil validasi lembar observasi aktivitas guru dan hasil validasi lembar angket siswa. Hasil validasi terhadap Lembar Observasi Aktivitas Siswa yang diperoleh adalah rata-rata keseluruhan skor 3,08 dan persentase rata-rata keseluruhan validasi lembar aktivitas siswa yaitu 76,96\%. Maka berdasarkan kriteria kevalidan, Lembar Aktivitas Siswa tersebut memenuhi kriteria valid. Pada bagian tersebut seorang validator menyarankan agar petunjuk penggunaan Lembar Observasi Aktivitas Siswa yang awalnya menggunakan persentase banyak siswa yang menunjukkan indikator yang ada diganti dengan menuliskan deskripsi masingmasing skor untuk memudahkan tim observasi untuk menghitung banyak siswa yang sesuai dengan indikator tersebut. Sedangkan ratarata keseluruhan skor validasi 
Lembar Aktivitas Guru 3,15 dengan persentase rata-rata keseluruhan validasi Lembar Aktivitas guru sebesar 78,8\%. Berdasarkan kriteria kevalidan maka Lembar Aktivitas Guru tersebut memenuhi kriteria valid.

Lembar instrument yang terakhir yang divalidasi oleh Lembar Angket Respon Siswa. Hasil validasi yang dilakukan oleh dua validator menunjukkan ratarata keseluruhan skor validasi angket respon siswa sebesar 3,18 dan persentase rata-rata keseluruhan skor validasi Angket Respon Siswa yaitu 78,85\%. Maka berdasarkan kriteria kevalidan, angket respon siswa tersebut memenuhi kriteria valid.

\section{Hasil Uji Coba Lapangan}

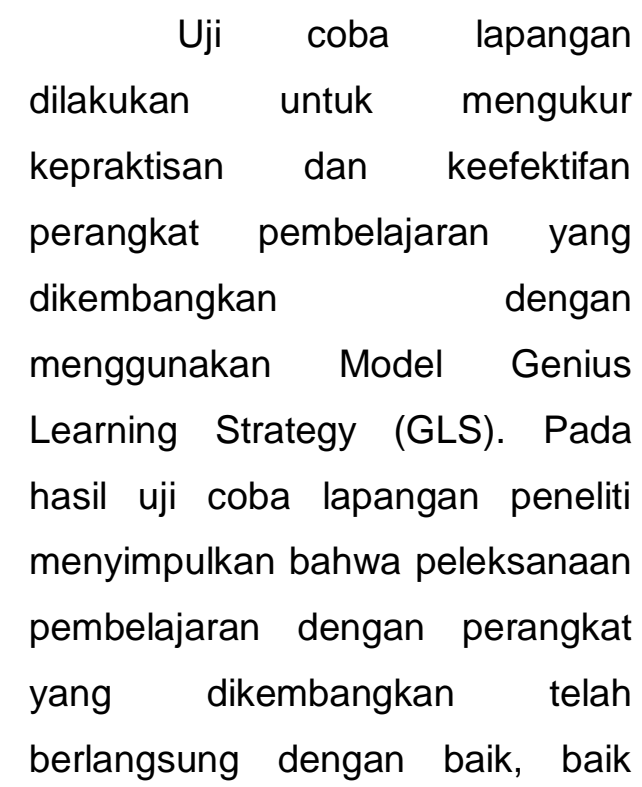

oleh guru maupun oleh siswa. Ketidaktuntasan hasil belajar yang dialamu oleh beberapa siswa yang cenderung disebabkan oleh faktor personal, misalnya siswa lupa rumus barisan dan deret yang akan digunakan, siswa tidak mampu memahami maksud dari soal yang diberikan dan siswa salah dalam menyelesaikan latihan soal yaitu pada operasi hitung.

\section{SIMPULAN DAN SARAN}

Dari hasil analisis tersebut dapat dikatakan bahwa perangkat pembelajaran yang dikembangkan dengan menggunakan model Genius Learning Strategytelah memenuhi tiga kriteria yaitu valid, praktis dan efektif. Kelebihan dari perangkat pembelajaran Lembar Kerja Siswa adalah membuat siswa lebih aktif dalam proses menyelesaikan latihan soal yang berkaitan dengan materi barisan dan deret dan meningkatkan interaksi antar siswa dan guru.

Selanjutnya, disarankan untuk melakukan uji coba pada sekolah lain yang berbeda kondisi untuk mendapatkan perangkat pembelajaran dengan model genius learning yang lebih berkualitas. Selain itu, tingkat 
keefektifan perangkat yang telah dikembangkan ini dapat ditemukan dengan melakukan penelitan eksperimen. Uji coba pada materi lain juga diperlukan untuk menguatkan hasil dari penelitian ini.

\section{DAFTAR PUSTAKA}

\begin{tabular}{|c|c|}
\hline \multirow[t]{13}{*}{ Azhar, } & $\begin{array}{cr}\text { Ervin. } & 2011 . \\
\text { Pengembangan Perangkat }\end{array}$ \\
\hline & Pembelajaran Teori \\
\hline & Peluang Berbasis RME \\
\hline & Meningkatkan \\
\hline & $\begin{array}{r}\text { an, } \begin{array}{r}\text { Penalaran } \\
\text { Komunikasi }\end{array}\end{array}$ \\
\hline & $\begin{array}{ll}\text { Dan } & \text { Komunikasi } \\
\text { Matematika } & \text { Siswa SLTA. }\end{array}$ \\
\hline & disajikan dalam \\
\hline & Nasional \\
\hline & Matematika dan \\
\hline & \multirow{3}{*}{$\begin{array}{l}\text { dan } \\
\text { Matematika, } \\
\text { Pendidikan } \\
\text { FMIPA UNY, } \\
\text { 3 Desember }\end{array}$} \\
\hline & \\
\hline & \\
\hline & \\
\hline
\end{tabular}

Bela, M.E. 2018. Pengembangan Perangkat Pembelajaran Kontekstual Untuk Materi Sistem Persamaan Linear Dua Variabel Di Kelas X Siswa SMK. Jurnal IImiah Pendidikan Citra Bakti Vol. 5 No.1 Ngada: STKIP Citra Bakti

Plomp, Tj. 1997. Educational Design: Introduction. From Tjeerd Plomp (eds). Educational \& Training System Design: Introduction. Design of Education and Training (in Dutch). Utrecht (the Netherlands): Lemma. Netherland.Faculty of Educational Science and Technology, University of Twente.

Plomp, Tjeerd \& Nienke Nieveen. 2007. An Introduction to Educational Design Research. Proceedings of the seminar conducted at the East China Normal University, Shanghai (PR China), 23-26 November 2007.

Soedjadi, R, 2000. Kiat Pendidikan Matematika Di Indonesia: Konstatasi Keadaan Masa Kini Menuju Harapan Masa Depan. Jakarta: Dirjen Dikti Depdiknas 